\title{
Ergonomic Troly Design for Increasing Productivity in PG Jatibarang Brebes
}

\author{
Akh. Sokhibi ${ }^{1}$, Mia Ajeng Alifiana ${ }^{2}$ \\ \{Akh.Sokhibi@umk.ac.id¹, Mia.ajeng@umk.ac.id² \\ Departement of Industrial Engineering, Faculty of Engineering, Muria Kudus University ${ }^{1}$, \\ Departement of Management, Fakulty of Economics And Business, Muria Kudus University ${ }^{2}$
}

\begin{abstract}
Work position is one aspect that must be considered in work. An uncomfortable work position will quickly cause fatigue and can reduce productivity. At the Jatibarang Brebes PG Finishing Station, there is a work position that does not pay attention to ergonomic aspects, namely the trolley operator carries sugar to the scale using a single wheel trolley. so that it will cause fatigue and decreased productivity. The research method used is the trolley operator anthropometry measurement, namely standing elbow height and hand grip diameter. Whereas production can be done by comparing output before and after using ergonomic trolleys. The results of this study produce ergonomic trolleys with trolley height $101.79 \mathrm{~cm}$, hand hand diameter $3.81 \mathrm{~cm}$, trolley width $50 \mathrm{~cm}$ and trolley length $70 \mathrm{~cm}$. Productivity generated after the ergonomic trolley application is $25.2 \%$.
\end{abstract}

Keywords: design, ergonomic, productivity, trolley.

\section{Introduction}

Sugar Factories are assets owned by post-independence Indonesia. One of the sugar factories which is a legacy of the Dutch heritage is the PG Jatibarang Brebes. The PG Jatibarang is located in Jatibarang Subdistrict, Brebes Regency, Central Java Province, which is based in PTPN IX. In general, the process of making sugar in the sugar factory of the Dutch heritage is divided into several stages, namely the stage of sugar cane grinding at the grinding station, the purification stage at the middle plant station, the crystallization stage at the princess station, the packing stage at the final station.

At this finishing station, the sugar that comes out of the puteran station is then packed in a $50 \mathrm{~kg}$ sack and then the sugar is carried by the operator using a one-wheel trolley to the scales. Looking at the working position of the sugar carrier operator by using a trolley with one wheel, it can be seen from the ergonomics aspect that the work position will quickly cause fatigue and quickly cause a decrease in the level of productivity.[1] To overcome the problem of work position, it is necessary to improve the work facilities used, namely designing an ergonomic trolley for the sugar carrier at the finishing station. [2] 


\section{Research Method}

Ergonomic trolley design research to increase productivity is carried out with anthropometric measurement methods on sugar transport operators. The object of this research is PG Jatibarang Brebes. The variables used in this research are trolley operator anthropometric data measurement, measurement of trolley operator process time and measuring productivity levels.[3] The stages of the research that will be carried out are as follows:

1) Data collection

Anthropometric data (elbow standing and hand-held diameter), sugar transport time data before and after the application of ergonomic trolley, peformance rating before and after applied the ergonomic trolley, allowance before and after applied the ergonomic trolley[4]

2) Data test

Normaly distribution anthropometri data test, Uniform anthropometri data test, adequacy anthropometri data test, Uniform sugar transport time before and after the application of ergonomic trolley data test, and adequacy sugar transport time before and after the application of ergonomic trolley data test.

3) Data processing

Anthropometric data used to determine percentile values. If the percentile value has been obtained, then the size of the ergonomic trolley can be design. To determine the value of productivity, the comparison value was calculated from before and after the application of ergonomic trolley.[5]

4) Trolley design

Use autocad software to design ergonomic trolleys.

5) Conclusion

\section{Result and Discussion}

\subsection{Anthropometric Data Trolley Operator}

Anthropometry data for trolley operators needed for trolley design are high elbow standing and hand held diameter. Table 1 shows anthropometric data from the trolley operator. 
Table 1. Anthropometry Data For Trolley Operators.

\begin{tabular}{cccccc}
\hline Operator & $\begin{array}{c}\text { High Elbows } \\
\text { Standing } \\
(\mathrm{Cm})\end{array}$ & $\begin{array}{c}\text { Hand-Held } \\
\text { Diameter } \\
(\mathrm{Cm})\end{array}$ & Operator & $\begin{array}{c}\text { High Elbows } \\
\text { Standing } \\
(\mathrm{Cm})\end{array}$ & $\begin{array}{c}\text { Hand-Held } \\
\text { Diameter } \\
(\mathrm{Cm})\end{array}$ \\
\hline 1 & 105 & 6 & 16 & 104 & 6 \\
2 & 106 & 7 & 17 & 102 & 6 \\
3 & 107 & 5 & 18 & 103 & 7 \\
4 & 103 & 7 & 19 & 102 & 5 \\
5 & 103 & 5 & 20 & 102 & 7 \\
6 & 102 & 6 & 21 & 105 & 6 \\
7 & 105 & 6 & 22 & 107 & 6 \\
8 & 107 & 7 & 23 & 106 & 7 \\
9 & 105 & 5 & 24 & 103 & 5 \\
10 & 108 & 5 & 25 & 104 & 6 \\
11 & 104 & 6 & 26 & 104 & 6 \\
12 & 106 & 5 & 27 & 107 & 5 \\
13 & 106 & 7 & 28 & 107 & 7 \\
14 & 103 & 6 & 29 & 106 & 5 \\
15 & 107 & 5 & 30 & 105 & \\
\hline
\end{tabular}

After the trolley operator anthropometric data was obtained, the next step were:

1) Measure the dimensions of sugar sacks

Dimensions of the sack sugar were used to determine the length and width of the trolley to be designed. For the size of the sack of sugar $=50 \mathrm{~cm}$ and for the length of the sack of sugar $=70 \mathrm{~cm}$.

2) Test the normality of trolley operator anthropometric data

SPSS software is used with a 95\% confidence level, and with the Statistical Test using the Kolmogorov-Smirnov Test. then the data was declared to be normally distributed if Sig. $>\alpha$, then H0 is accepted and If Sig. $<\alpha$, then H0 is rejected.

Table 2. Test the normality of trolley operator anthropometric data.

\begin{tabular}{cccc}
\hline Anthropometric Data & N & Sig. & $\alpha$ \\
\hline Elbow Standing & 30 & 0,559 & 0,05 \\
Hand grip diameter & 30 & 0,072 & 0,05 \\
\hline
\end{tabular}

3) Anthropometric data uniformity test for trolley operator

Uniformity test Anthropometric data on trolley operators is carried out with the aim to test whether the data obtained is uniform or not. the data is declared uniform if the data is between the upper control limit and the lower control limit. Table 3 shows the results of the trolley operator anthropometric data uniformity test.

Table 3. Result of Anthropometric data uniformity test for trolley operator.

\begin{tabular}{ccccc}
\hline Anthropometric Data & $\bar{X}$ & $\sigma$ & BKA & BKB \\
\hline Elbow Standing & 104,8 & 1,83 & 108,4 & 101,2
\end{tabular}


4) Adequacy test of anthropometric data on trolley operator Adequacy test of anthropometric data trolley operator aims to test whether the data used is sufficient or not. Table 4 shows the results of the calculation of the adequacy test of the anthropometric data of the trolley operator.

Tabel 4. Results of the anthropometric data adequacy test from the trolley operator

\begin{tabular}{lcc}
\hline Anthropometric Data & N & N' \\
\hline Elbow Standing & 30 & 1 \\
Hand grip diameter & 30 & 29 \\
\hline
\end{tabular}

5) Calculate the percentile value Persentile size was the size used as the basis for determining the trolley size to be designed. The persentile measure used in the design of trolley was a 5-th percentile, 50-th percentile, 95 -th percentile. Table 5 shows the value of the percentile of trolley design.

Tabel 5. The value of the percentile of trolley design.

\begin{tabular}{lccc}
\hline \multirow{2}{*}{ Anthropometric Data } & \multicolumn{3}{c}{ Persentile $(\mathrm{cm})$} \\
\cline { 2 - 4 } & $5^{\text {th }}$ & $5^{\text {th }}$ & 95-th $^{\text {th }}$ \\
\hline Elbow Standing & 101,79 & 104,8 & 107,81 \\
Hand Grip Diameter & 3,81 & 5,9 & 7,53 \\
\hline
\end{tabular}

6) Ergonomic trolley design

Ergonomics trolleys are designed based on percentile values. for high size the trolley is taken from the 5-th percentile value of the standing elbow that is $101.79 \mathrm{~cm}$. while for the diameter size the trolley handle is taken from the 5-th percentile value of the hand grip diameter of $3.81 \mathrm{~cm}$

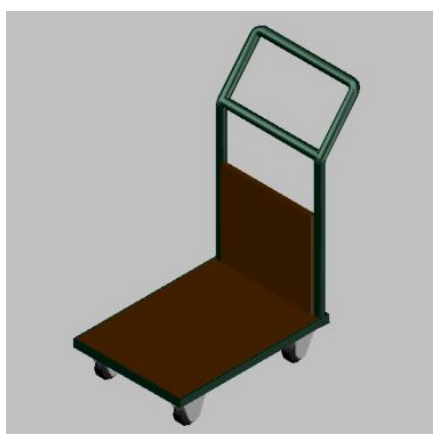

Fig. 1. Ergonomic Trolley Design. 


\subsection{Productivity Analysis}

Productivity values from the application of ergonomic trolleys can be calculated by the following steps:

1) Calculate Trolley operator Time Data before and after the application of ergonomic trolleys.

Table 6. Trolley operator Time Data.

\begin{tabular}{|c|c|c|}
\hline $\begin{array}{l}\text { Trolley } \\
\text { Operator }\end{array}$ & $\begin{array}{l}\text { Before The Application Of } \\
\text { Ergonomic Trolley }\end{array}$ & $\begin{array}{c}\text { After The Application Of Ergonomic } \\
\text { Trolley }\end{array}$ \\
\hline 1 & 19 & 16 \\
\hline 2 & 20 & 15 \\
\hline 3 & 20 & 16 \\
\hline 4 & 21 & 16 \\
\hline 5 & 18 & 15 \\
\hline 6 & 19 & 17 \\
\hline 7 & 19 & 15 \\
\hline 8 & 18 & 17 \\
\hline 9 & 17 & 18 \\
\hline 10 & 21 & 17 \\
\hline 11 & 17 & 18 \\
\hline 12 & 20 & 17 \\
\hline 13 & 21 & 17 \\
\hline 14 & 19 & 18 \\
\hline 15 & 19 & 16 \\
\hline 16 & 18 & 15 \\
\hline 17 & 17 & 15 \\
\hline 18 & 18 & 17 \\
\hline 19 & 18 & 16 \\
\hline 20 & 21 & 16 \\
\hline 21 & 21 & 18 \\
\hline 22 & 20 & 17 \\
\hline 23 & 19 & 16 \\
\hline 24 & 17 & 15 \\
\hline 25 & 17 & 15 \\
\hline 26 & 18 & 16 \\
\hline 27 & 21 & 18 \\
\hline 28 & 20 & 18 \\
\hline 29 & 17 & 17 \\
\hline 30 & 18 & 15 \\
\hline
\end{tabular}

2) Time Data uniformity test for trolley operators before and after applied ergonomic trolley.

Table 7. Results Time Data Uniformity Test For Trolley Operators Before And After Applied Ergonomic

\begin{tabular}{ccccc} 
Data & $\bar{X}$ & $\sigma$ & BKA & BKB \\
\hline Before the applied of ergonomic trolley & 18,93 & 1,44 & 21,81 & 16,05
\end{tabular}


3) Calculate the value of performance rating before and after applied the ergonomic trolley

Table 8. Performance Rating Before And After Applied The Ergonomic Trolley.

\begin{tabular}{|c|c|c|}
\hline $\begin{array}{l}\text { Perfonmance } \\
\text { Rating }\end{array}$ & $\begin{array}{l}\text { Before the applied of ergonomic } \\
\text { trolley }\end{array}$ & $\begin{array}{l}\text { After the applied of ergonomic } \\
\text { trolley }\end{array}$ \\
\hline Skill & 0,00 & 0,00 \\
\hline Effort & 0,05 & 0,05 \\
\hline Conditions & $-0,03$ & $-0,03$ \\
\hline Consistency & 0,00 & 0,00 \\
\hline Total & 0,02 & 0,02 \\
\hline
\end{tabular}

Total value of peformance rating before and after the applied of ergonomic trolley was $(\mathrm{P})=1+0.02=1.02$

4) Calculate the allowance before and after applied the ergonomic trolley.

Table 9. Allowance Before And After Applied The Ergonomic Trolley.

\begin{tabular}{|c|c|c|}
\hline Adequacy test & $\begin{array}{l}\text { Before the applied of } \\
\text { ergonomic trolley }\end{array}$ & $\begin{array}{c}\text { After the applied of ergonomic } \\
\text { trolley }\end{array}$ \\
\hline Strength & $20 \%$ & $16 \%$ \\
\hline Work attitude & $1,5 \%$ & $1 \%$ \\
\hline Movement & $3 \%$ & $2 \%$ \\
\hline Fatigue & $1 \%$ & $1 \%$ \\
\hline Temperature & $5 \%$ & $5 \%$ \\
\hline Atmosphere & $2 \%$ & $2 \%$ \\
\hline Environmen & $4 \%$ & $4 \%$ \\
\hline Total & $36,5 \%$ & $31 \%$ \\
\hline
\end{tabular}

5) Calculate the standard time before and after the application of ergonomic trolleys.

a. Before applied the ergonomic trolley

$$
\begin{aligned}
& \text { Cycle Time }=\bar{X}=\frac{\sum_{i=1}^{n=30} x}{n}=\frac{568}{30}=18,93 \text { second } / \text { sack } \\
& \text { Normal Time }=\text { Ws } \times \text { PR }=18,93 \times 1,02=19,31 \text { second } / \text { sack } \\
& \text { Standard Time }=\mathrm{Wn} \times\left(\frac{100 \%}{100 \%-\text { Allowance }}\right) \\
& =19,31 \times\left(\frac{100 \%}{100 \%-36,5 \%}\right) \\
& =30,31 \mathrm{~second} / \mathrm{sack}=0,0084 \text { hour } / \mathrm{sack}
\end{aligned}
$$

b. After applied the ergonomic trolley 


$$
\begin{aligned}
& \text { Cycle Time }=\overline{\mathrm{X}}=\frac{\sum_{\mathrm{i}=1}^{\mathrm{n}=30} \mathrm{x}}{\mathrm{n}}=\frac{492}{30}=16,4 \text { second } / \mathrm{sack} \\
& \text { Normal Time }(\mathrm{Wn})=\mathrm{W} \text { s } \mathrm{PR}=16,4 \times 1,02=16,73 \text { second } / \mathrm{sack}
\end{aligned}
$$

$$
\begin{aligned}
\text { Standard Time } & =\operatorname{Wn} \times\left(\frac{100 \%}{100 \%-\text { Allowance }}\right) \\
& =16,73 \times\left(\frac{100 \%}{100 \%-31 \%}\right)
\end{aligned}
$$$$
=24,26 \mathrm{~second} / \mathrm{sack}=0,0067 \text { hour } / \mathrm{sack}
$$

6) Calculate the standard output before and after the application of an ergonomic trolley.

a. Before Applied The Ergonomic Trolley.

$$
\text { Output } \text { Standart }=\frac{1}{W b}=\frac{1}{0,0084}=119,04 \mathrm{sack} / \mathrm{hour} \approx 119 \mathrm{sack} / \mathrm{hour}
$$

b. After Applied The Ergonomic Trolley.

$$
\text { Output } \text { Standar }=\frac{1}{W b}=\frac{1}{0,0067}=149,2 \text { sack/hour } \approx 149 \text { sack } / \text { hour }
$$

7) Calculate the value of productivity

Productivity can be calculated by the following equation:

$$
\text { Productivity }=\frac{\text { Output } 2-\text { Output1 }}{\text { Output } 1} \times 100 \%=\frac{149-119}{119} \times 100 \%=25,2 \%
$$

There was an increase in the number of products with 30 sacks / hour and an increase in output productivity of $25.2 \%$.

\section{Conclusion}

The conclusion of this research is ergonomic trolley design with trolley height size of $101.79 \mathrm{~cm}$, trolley hand grip diameter size of $3.81 \mathrm{~cm}$, trolley width size of $50 \mathrm{~cm}$ and trolley length size of $70 \mathrm{~cm}$. Then after the application of ergonomics trolleys obtained an increase in productivity of $25.2 \%$.

\section{References}

[1] Evrianto, "Definisi Produktivitas," 2012.

[2] S. Pheasant, Bodyspace: Antropometry, ergonomics and the Design of work, vol. 24, no. 4. 2003.

[3] S. Pheasant, Bodyspace: Anthropometry, Ergonomics and the Design of Work, Second Edition. 2003.

[4] W. S. Wilkinson, "Designing trolleys for the new millennia - An engineering analysis and human factors concepts approach," in Proceedings of the XIVth Triennial Congress of the International Ergonomics Association and 44th Annual Meeting of the Human Factors and Ergonomics Association, "Ergonomics for the New Millennium," 2000, p. 405.

[5] S. Wignjosoebroto, "Evaluasi Ergonomis Dalam Proses Perancangan Produk," Eval. Ergon. Dalam Proses Peranc. Prod., 2000. 